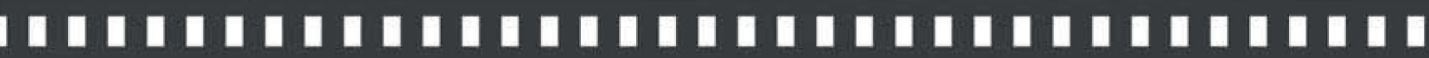 Transformações e inovações do design gráfico punk no seriado Peter Punk da Disney

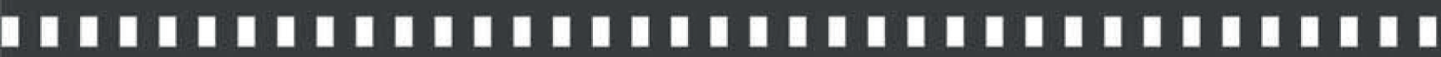

\author{
Regina Rossetti \\ David Santoro Junior
}

Artigo recebido em: 08/07/2015

Artigo aprovado em: 08/05/2016 


\title{
Transformações e inovações do designn gráfico punk no seriado Peter Punk da Disney
}

Transformations and innovations of punk graphic design in

Peter Punk series from Disney

Regina Rossetti*

David Santoro Junior**

Resumo: O movimento punk é um exemplo de cultura periférica que atualmente influencia a cultura dominante. Este artigo objetiva apontar quais foram as mudanças e as inovações que o design gráfico do punk teve de sofrer para adaptar-se à série Peter Punk, exibido pelo canal Disney XD. Através de revisão da literatura e análise de imagens, é possível concluir que o design gráfico da série absorveu o estilo punk com outras influências, mas sem a espontaneidade característica do punk.

Palavras-chave: Comunicação e inovação; Movimento punk; Disney; Design gráfico.

\begin{abstract}
The punk movement is an example of peripheral culture that currently influences the dominant culture. This article aims to point out what were the changes and the innovations that the punk graphic design had to struggle to adapt itself to the series Peter Punk, exhibited by Disney XD channel. Through literature review and analysis of images, it is possible to conclude that the show's graphic design absorbed the punk style with other influences, but without the spontaneity of punk.
\end{abstract}

Keywords: Communication and innovation; Punk movement; Disney; Graphic design.

*Professora do PPGCOM da Universidade Municipal de São Caetano do Sul e professora na Universidade Paulista. Doutora em Filosofia pela USP com pósdoutorado pela mesma Universidade.

**Mestre em Comunicação pela USCS. 


\section{Introdução}

Este artigo objetiva apontar as transformações e as inovações que o design gráfico do punk sofreu para adequar-se ao seriado infantojuvenil Peter Punk do Canal Disney XD, porque as imagens da série que foram analisadas apresentam semelhanças com o estilo da pop art, do dadaísmo e do design gráfico do punk, que utilizam a técnica do contraste definida por Dondis (2000), com apropriações de imagens e textos de revistas e jornais.

Há também a preocupação em contextualizar as principais características dos estilos do punk e da Disney, que são culturas opostas: a Disney aproxima-se do poder da cultura dominante, que segundo Cuche (1999) é aquela que possui o poder de impor-se sobre as demais pela sua força econômica ou por valores que são aceitos pelas classes dominantes; o movimento punk, por sua vez, pode ser enquadrado em um grupo dominado que não aceita esta imposição e, como representante de uma contracultura, opõe-se, sugerindo uma forma alternativa de viver em sociedade.

A técnica da harmonia explicada por Dondis (2000) está presente no design de alguns produtos Disney, pois ela remete à segurança e à estabilidade, que são elementos das narrativas produzidas pela empresa, nas quais os protagonistas das histórias enfrentam conflitos e os superam, transmitindo a mensagem de que o bem sempre vencerá o mal.

O punk utiliza a técnica do contraste, que alinha-se à anarquia, que é uma forma simbólica de reconstruir os valores sociais defendidos por esse grupo. Há pontos convergentes como a música, que para ambos é de fundamental importância para a transmissão de suas opiniões e para a defesa do meio ambiente. O seriado Peter Punk pode ser visto como ponto de confluência dessas culturas, por meio de pesquisa bibliográfica com autores como Dondis (2000), Elger (2010), Hollis (2010) e Honnef (2004), que contextualizam o design gráfico e movimentos como a pop art, o dadaísmo e o punk, e a análise de 13 imagens que comprovam a influência desses 
movimentos na linguagem gráfica do seriado e indicam quais foram as transformações e as inovações que resultaram dessa intersecção.

\section{Principais características do}

\section{design gráfico do punk}

Para Hollis (2010), o design gráfico do punk refletiu o descontentamento que originou o movimento punk. A falta de perspectiva de emprego para os jovens designers os levou a afrontar sua profissão, com produções toscas e agressivas, destruindo o conceito estético dos anos 1970, que era influenciado por composições tecnológicas e tinha uma linguagem complexa. O princípio "faça você mesmo" desprezava a técnica e priorizava o que havia a ser dito, a agressividade buscava conquistar um espaço de expressão, o objetivo era ser ouvido e apresentar o descontentamento político e social do final dos anos 1970.

Repentinamente tudo é punk ou à la punk. Nas escolas de arte, os estudantes punks estão criando um novo visual nas artes gráficas. Um visual rude e malcriado, uma espécie de retomada do Dadá (Dadaísmo, corrente de vanguarda europeia de cerca dos anos 20, um movimento anarquista, a antiarte para acabar com a arte); ou, recapitulando um dos manifestos futuristas de cerca de 1910: "Rebele-se contra a tirania da palavra harmonia e bom gosto" (BIVAR, 2001, p. 50).

A agitação política na Europa após a Primeira Guerra Mundial causou discussões políticas que influenciaram as artes, do que resultou, por exemplo, a introdução pelos vanguardistas de uma nova forma de usar a tipologia e o alfabeto para criar imagens. A simetria habitual empregada nos textos dividiu espaço com uma diagramação inovadora, na qual o texto não servia apenas para ser 
lido e sua disposição reforçava o sentido da mensagem. Rompeu-se o paradigma de que cada página deveria contar uma história.

O poeta italiano Fillipo Tommaso Marinetti liderou o movimento e publicou o manifesto futurista em Paris, em 1909, valorizando as modernidades da época, como a velocidade, os automóveis, os aviões e a guerra, o que causou muita polêmica na Europa. Em 1914, Marinetti publicou o livro Zang Tumb Tumb, que foi chamado por ele de Parole in Libertà. Uma pintura verbal para celebrar a Batalha de Trípoli, a obra usava fontes de tamanhos diferentes para representar o som das palavras, além de contrariar a sintaxe (ordenação das palavras e frases em um discurso para que haja coerência) ao dispor os substantivos de forma aleatória. Assim, o significado variava de acordo com a visão de quem apreciasse o trabalho.

O final dos anos 1970 foi semelhante ao momento de tensão em que o dadaísmo surgiu. Naquela década, o movimento punk emergiu nos grandes centros e deixou de ser uma cultura periférica. A incerteza e a insegurança se refletiam tanto nos trabalhos gráficos dos dadaístas como no design gráfico do punk, já que ambos optaram pela instabilidade ao invés do equilíbrio, pela assimetria ao invés da simetria.

O equilíbrio é utilizado pelos designers para proporcionar à composição um centro de estabilidade com pesos iguais, enquanto a instabilidade representa a ausência de equilíbrio, reproduzindo visualmente a inquietude e a provocação. $\mathrm{O}$ equilíbrio assimétrico é obtido por meio da variação de elementos que se compensam, não necessariamente com pesos iguais, e pode ser percebido, além dos trabalhos dos dadaístas e dos designers punks, na obra de Kandinsky (DONDIS, 2000). Escolha semelhante foi feita por Mondrian, que produziu pinturas com equilíbrio assimétrico e com muita tensão entre os elementos, e mesmo assim alcançou harmonia absoluta (MEEGS, 2013).

Segundo Hollis (2010), os construtivistas rejeitavam a ideia de que uma obra de arte fosse única, considerando-a uma visão 
burguesa que defendia a aura da obra, enquanto a produção de arte por processos mecânicos poderia gerar várias unidades e espalhar a obra por locais diferentes, comunicando-a a um número maior de pessoas.

Meegs (2013) aborda o ponto de vista de artistas como Maliévitch e Kandinsky, que afirmavam que a arte deveria ser uma atividade essencialmente espiritual, separada das necessidades utilitárias da sociedade, e rejeitavam seu papel político e social, por acreditarem que o único objetivo da arte era revelar as percepções do mundo mediante formas inventadas no espaço e no tempo.

Os designers punks assumiram a técnica desenvolvida pelos dadaístas e artistas da pop art para produzir mensagens aos jovens do movimento que transmitissem a visão contestadora e os valores defendidos por esta cultura.

A objetividade alemã é representada pela Escola de Arte Bauhaus, cujo primeiro logotipo utilizava um tipo medieval e uma figura de braços e pernas abertos, que lembrava um construtor. Em 1924, Oskar Schlemmer criou uma nova marca, com tipos sem serifa e um rosto geométrico de perfil. Sua simplicidade facilitava a reprodução em vários meios de impressão sem que a marca perdesse sua principal característica. $\mathrm{O}$ trabalho de designers como Weimar e Max Burchartz deu continuidade às ideias dadaístas e estabeleceu parâmetros para a elaboração de peças publicitárias, como a análise do emissor e receptor, o papel da propaganda, a sua objetividade, a sua capacidade de envolver o leitor e os pontos de leitura de uma composição, que direcionam o olhar para os elementos importantes da mensagem.

Hollis (2010) afirma que os designers utilizavam a fotografia como complemento da mensagem da publicidade. John Heartfield produzia colagens e fusões irônicas. Seu trabalho mais conhecido é um pôster para o Partido Comunista, cujo número nas eleições era o cinco. Nele, várias mãos abertas reforçam a mensagem de que, para mandar o inimigo para o olho da rua, era preciso votar no número do partido. Um trabalho polêmico de Heartfield foi publicado na 
Revista dos Trabalhadores, em que uma foto de Hitler saudando seus seguidores foi alterada para mostrar que ele recebia dinheiro das elites, representadas por um homem bem maior que o futuro ditador. O recurso da dimensão mostrava que Hitler era manipulado pelas classes dominantes e não tinha a liberdade e o poder de ação que dizia.

O partido nazista chegou ao poder em 1933 e a escola Bauhaus foi fechada, uma represália provavelmente por causa do partido que a vanguarda representava. A linguagem desenvolvida pelos modernistas foi incorporada ao regime nazista. Exilados, os designers alemães propagaram suas técnicas pela Europa e pelos Estados Unidos (MEEGS, 2013).

\section{A influência do dadaísmo no movimento punk}

A arte produzida pelos punks nos anos 1970 possui pontos em comum com a dadaísta, como o rompimento com a cultura estabelecida. Os dadaístas ergueram-se contra os padrões estéticos da arte no início do século XX e sugeriram a caótica antiarte. Com exceção de Jamie Reid e Winston Smith, que planejaram a linguagem visual dos Sex Pistols e dos Dead Kennedys, o design gráfico do punk foi desenvolvido por artistas como Arturo Vega, criador do logotipo dos Ramones, que, como a maioria, não tinha conhecimento artístico e era diletante. Com base no princípio "faça você mesmo", construiu-se uma linguagem de comunicação visual, escrita e musical.

Embora o conhecimento sobre as artes seja um ponto que distingue os movimentos punk e dadaísta, a iniciativa de criar novos caminhos e meios para expor ideias é de certa forma comum entre os dois. Os dadaístas criavam suas próprias revistas, e os punks, seus fanzines, pois os meios tradicionais não abriam espaço para essas culturas. Outras semelhanças são as apropriações, a agressividade e as provocações.

Os trabalhos de Hans Arp, Raoul Hausmann, John Heartfield 
e Marcel Duchamp resumem a essência do estilo dadá e também evidenciam a influência no design gráfico do punk. Arp inovou no processo criativo ao incluir outros artistas e profissionais na produção de suas obras. A cocriação buscava um caráter impessoal e a realização da arte pelo acaso, opondo-se à genialidade artística, que era o caminho habitual. Na obra Colagem Disposta Segundo as Leis do Acaso, é possível perceber ordem e coerência no posicionamento supostamente aleatório dos elementos. Há muita semelhança entre ela e a contracapa do álbum Never Mind the Bollocks, Here's the Sex Pistols, desenvolvida por Jamie Reid.

Raoul Hausmann, por sua vez, mudou-se para Berlim ainda jovem e, influenciado pelo pai, iniciou seus estudos na pintura, interessando-se pelo expressionismo e pelo futurismo. Antes da Primeira Guerra Mundial já escrevia críticas de arte na revista Der Stum, em Zurique, com Hans Arp, Richard Huelsembeck e Tristam Tzara. Tornou-se figura importante do dadaísmo por sua contribuição no desenvolvimento da fotomontagem de estilo alemão, que se diferenciava do cubista devido à inserção de textos na composição.

Marcel Duchamp foi um importante artista moderno pelo desenvolvimento do conceito ready made, segundo o qual qualquer objeto está pronto para a arte, bastando ser apresentado de maneira adequada. Suas obras Roda de Bicicleta e Chafariz foram exibidas em uma exposição de arte em Nova York e foram rejeitadas, fato que confirmou seu rompimento com o mito do artista criador e gênio e com as expectativas do público (ELGER, 2010).

\section{O punk no contexto do design gráfico}

Acreditava-se que o estilo suíço, originário do modernismo, era o modelo de bom gosto que todos deveriam seguir para construir uma imagem e aplicá-la corretamente em meios diversos. Assim, o design tornou-se formal e naturalmente chegou ao esgotamento.

Em contraposição ao padrão estabelecido, o punk 
desconstruía o design e defendia a anarquia, o caos e a linguagem dos jovens londrinos, recheada de rebeldia, energia e agressividade. Suas composições traziam imagens retiradas de jornais e textos escritos à mão ou em máquina de escrever. A montagem era a matriz para a produção em série, por meio de copiadoras ou formas baratas de impressão.

Nos Estados Unidos, o design gráfico do punk foi desenvolvido pela intuição de artistas amadores em trabalhos marcantes, como o logotipo dos Ramones, criado por Arturo Vega. Ao lado da marca dos Rolling Stones, criada com base nos lábios de Mick Jagger, é o símbolo mais icônico do rock. Vega tornouse amigo dos integrantes dos Ramones e passou a trabalhar com eles na montagem dos equipamentos de som e na iluminação das apresentações da banda. Como tinha talento artístico, acabou produzindo volantes e folhetos para os shows das bandas punks no circuito nova-iorquino (TRUE, 2013).

A explicação de Vega para o símbolo é o de que, para ele, os Ramones refletiam o espírito e o caráter norte-americanos: eram jovens e tinham uma agressividade inocente, que o fazia se lembrar de sua visita a Washington e de como ficou impressionado com a atmosfera da Casa Branca. Tal associação o levou a adaptar a águia oficial para a marca da banda: o ramo de oliveira foi substituído por uma macieira, porque os Ramones eram norte-americanos como uma torta de maçã; as setas foram mantidas acima da cabeça da águia, para representar a agressividade e a defesa da banda, caso fosse criticada; o taco de beisebol é uma homenagem a Johnny, que era fã do esporte; e a flâmula, em vez da inscrição original ("De muitos, o único"), recebeu a frase "Hey, Ho, Let's Go", o grito de guerra da banda.

Desse modo, o logotipo criado por Arturo Vega mostra símbolos que representam a filosofia punk, ligada ao dadaísmo. A subversão está na ousadia de utilizar uma marca oficial dos Estados Unidos; na apropriação, no uso da águia e no novo significado dado a ela; na agressividade, nas flechas e no taco de beisebol; e no "faça 
você mesmo", no fato de Vega não ser um artista formado e mesmo assim fazer um trabalho com seu talento e intuição.

Em 1977, o editor da revista Vogue, Terry Jones, publicou Um livro punk diferente, que reunia elementos experimentais, como imagens de jornais, textos impressos reaproveitados, fotos ampliadas, imagens distorcidas com o efeito de movimento do papel nas copiadoras, fotos instantâneas sem a calibração das cores, e fotografias com interferências feitas a caneta ou com estilete. A inovação foi transformar as limitações da tecnologia e dos originais manipulados em algo positivo; o que era um defeito ou algo inapropriado tornou-se uma linguagem.

Rapidamente, o estilo agressivo e cru do design punk foi adotado por editores de revistas de comportamento jovem, como a Face, do editor de arte Neville Brody. Porém, isso acabou adequando a nova linguagem, já que essa apropriação consistia em aplicar o estilo visual punk, com suas variações de fonte e ruídos nas imagens, por meio de recursos digitais ou da habilidade dos diretores de arte da equipe, ou seja, as interferências não eram naturais como no design punk, e sim criadas especificamente para as matérias e para o projeto gráfico da revista (HOLLIS, 2010).

\section{A identidade visual dos Sex Pistols}

O discurso dos Sex Pistols englobava um sentimento comum e a voz das classes discriminadas e o trabalho da banda transcenderam a música e atingiram a performance, unindo mensagem, música e estilo visual. O trabalho de Jamie Reid para os Pistols rompeu com as normas institucionalizadas pela arte e pelo design gráfico. À primeira vista, a obra aparenta ser simplória, pobre e amadora, mas, na época em que foi criada, destruiu os mais sólidos conceitos do que deveria ser uma peça de design gráfico.

A autenticidade do legado dos Sex Pistols criou uma posição única na história do rock, e prova disso é a associação direta que as pessoas fazem entre a banda e o movimento punk. Quando se 
fala em punk, logo se pensa na música e no visual dos Sex Pistols, pois a linguagem visual desenvolvida por Reid foi incorporada pelo movimento, e a sincronia de seu trabalho gráfico com a banda fez com que imagem e som compusessem uma mensagem única, uma complementando a outra, estimulando a percepção sensorial.

Em 1979, o trabalho de Reid se refletiu em um pôster dos Dead Kennedys para o compacto California Über Alles. A ilustração era composta de uma multidão reunida no festival de Woodstock, com folhas de maconha em forma de suásticas, e a chamada dizia "Nunca confie em um hippie", seguida pelo nome da música. Essa mensagem irônica era uma crítica e um ataque aos hippies, que utilizavam um discurso libertário para obter lucros e poder sobre os jovens, em uma relação autoritária que contrariava o princípio punk de igualdade.

\section{A identidade visual dos Dead Kennedys}

O nome Dead Kennedys simboliza o fim do sonho norteamericano, em razão do assassinato de Robert Kennedy, que completava dez anos em 1978, quando a banda iniciou seu trabalho. O sarcasmo político já estava presente no single de estreia, California Über Alles, de 1979, que comparava a política do então governador da Califórnia, Jerry Brown, com as práticas fascistas. A comunicação visual ficou a cargo de Jamie Reid, que utilizou as frases "A música te mantém sob controle" e "Nunca confie em um hippie" para ressaltar a visão de Biafra em relação aos hippies, que haviam trocado o idealismo pela ganância.

As apresentações dos Dead Kennedys associavam música com a performance teatral do vocalista, que imitava ditadores e pastores embriagados. Biafra acreditava que a linguagem visual reforçaria sua mensagem, e fez uma parceria com Winston Smith para traduzir graficamente o trabalho do grupo.

O trabalho de Smith se caracterizava pela sofisticação, pela astúcia, pelo olhar afiado para o equilíbrio de suas montagens, pela 
ironia sarcástica e pelo uso do design gráfico para convencer. Além das capas polêmicas - como a do álbum Bedtime for Democracy, de 1986, que trazia um crucifixo tridimensional formado por notas de dólar -, seu trabalho mais reconhecido é o logotipo dos Dead Kennedys, uma marca simples, objetiva e direta, que une as letras $\mathrm{D}$ e $\mathrm{K}$ em uma única forma, com as cores preto e vermelho (OGG, 2014). Como mencionado, essas cores eram utilizadas pelos dadaístas, que associavam o preto ao poder do capitalismo, e o vermelho à força dos trabalhadores (HOLLIS, 2010). Desse modo, os trabalhos de Winston Smith e Jamie Reid guardam paralelos tanto pela criação de um sistema visual para o movimento punk como por sua influência sobre outros designers.

\section{A pop art versus o punk}

A pop art pode ser considerada uma resposta aos estudos de Walter Benjamin, que discutiram o papel das artes diante do advento das novas tecnologias e costumes à sociedade do início do século XX. Walter Benjamin abordou aspectos da arte moderna como a perda de sua aura, por ser produzida em série por meios mecânicos; a eliminação de características perceptíveis que identificavam seus autores; e a mudança na relação entre mensagem e receptor, já que o deslocamento para avaliar e contemplar uma obra deixou de ser necessário com sua produção em série (BENJAMIN, 1990).

A pop art surgiu paralelamente aos estudos culturais, iniciados na década de 1950 na Inglaterra com os objetivos de redimensionar o capital cultural, identificar os meios de produção que poderiam ser facilmente assimilados pela sociedade e analisar a influência e o impacto da cultura de massa na sociedade moderna (PRYSTHON, 2004).

O nome pop art é atribuído ao crítico de arte Lawrence Alloway, que explica que não batizou a nova vertente artística, mas apenas utilizou termos como "cultura de massa" e "popular" para contextualizar os aspectos criativos e conceituais da nova arte. 
O estilo encontrou terreno fértil nos Estados Unidos, local em que jovens artistas desenvolviam uma nova linguagem para a arte com as gírias das ruas. Nomes como Roy Lichtenstein, Claes Oldenburg e Andy Warhol produziam esculturas e pinturas com temas urbanos, como anúncios, cartazes de cinema e fotos de revistas com mensagens irônicas e críticas (HONNEF, 2004).

Politicamente, o estilo não apresentava nenhuma crítica que levasse à reflexão e, quando fazia algo de cunho social, não abalava a opinião pública, porque somente revelava mecanismos de manipulação. Tanto na Inglaterra como nos EUA, as obras eram influenciadas pelo fascínio que o desenvolvimento industrial, a cultura comercial e a prosperidade econômica causavam na sociedade. Após um período difícil em razão da Segunda Guerra Mundial, os artistas estavam lidando com a cultura de massa e adaptando ícones culturais que representavam a cultura do consumo.

Os principais nomes da pop art exploravam a cultura popular visual e, nos segmentos escolhidos por cada um, desenvolveram e renovaram seus estudos. Lichtenstein explorou a linguagem dos quadrinhos e dos meios impressos, com algumas obras mostrando as retículas da quadricromia utilizada na impressão, uma forma de desmistificar e comprovar a ilusão de ótica que o sistema gráfico constrói para que nuances e degradês sejam percebidos. Warhol utilizou marcas de produtos de consumo reconhecidas pela sociedade norte-americana, como a Coca-Cola e as sopas Campbell's, e preferia os métodos mecânicos, que possibilitavam que seus assistentes contribuíssem com a produção.

A pop art se assemelha ao dadaísmo nas apropriações de marcas e de imagens de personalidades, que ganhavam um novo sentido no contexto artístico em que eram empregadas. O princípio "pronto para a arte", desenvolvido por Marcel Duchamp, também está presente em obras de Andy Warhol, Mel Ramos e Claes Oldenburg. 


\section{Principais características da linguagem visual da Disney}

Nem sempre os ideais se tornam realidade, e para Walt Disney foi assim. Ele iniciou sua carreira com o objetivo de ser ilustrador, mas foi para Hollywood e voltou com um contrato rompido e sem perspectivas. Seu futuro não estava na ilustração ou na direção de filmes com personagens vivos; sua vocação era revolucionar os desenhos animados como ninguém havia feito.

Com sua capacidade de liderança e de inovação, Walt percebeu que seus artistas eram mais produtivos nos esboços do que na arte-final, por isso dividiu as funções de seu estúdio e contratou arte-finalistas para finalizarem os desenhos elaborados pelos ilustradores. Assim, introduziu o trabalho em equipe no mundo artístico (MOYA, 1996).

Os desenhistas de animação simplificavam a produção dos movimentos com repetições de um mesmo desenho. Como um bom observador, Walt percebeu que, na natureza, um movimento não é perfeito e as formas variam, por isso pediu que vários desenhos fossem feitos para uma sequência, assim atingindo uma suavidade e leveza muito próximas do natural. Isso rompeu o paradigma de que, para ter 24 desenhos com vida própria, uma animação deveria ter 24 poses que projetassem 24 quadros.

Para aprimorar suas produções e torná-las tão reais quanto possível, Walt investiu na pré-produção. Artistas consagrados, como Eva Gabor, posaram para os estúdios Disney a fim de inspirar a criação da personagem Gata Duquesa, de Aristogatas. Para ele, além de contarem uma boa história, as produções deveriam ser boas e naturais, e os envolvidos deveriam incorporar o espírito da empresa e dos projetos com que contribuíam.

Após a criação de um personagem, este era esculpido em tamanho humano para que a tridimensionalidade fosse percebida pelos desenhistas e a produção se enriquecesse visualmente. Em 
busca da perfeição e do equilíbrio, Walt Disney utilizou também técnicas de design que levam à precisão, como equilíbrio, simetria, regularidade, unicidade, previsibilidade, sutileza, exatidão e sequencialidade, entre outras (DONDIS, 2000). Isso refletia o posicionamento político e empresarial do estúdio, que sempre apoiou valores conservadores da sociedade norte-americana.

Com base nos bonecos, as cenas eram detalhadas no storyboard, buscando-se criatividade e liberdade de criação. Os quadros eram posteriormente analisados, alterados e descartados ou produzidos.

Os cenários eram desenvolvidos por profissionais especializados, que harmonizavam o fundo com os personagens. Nota-se nisso a preocupação com o princípio da figura e fundo, da Gestalt, segundo o qual o fundo tem a finalidade de apoiar a figura para que ela se destaque. O princípio da continuidade é visto nos detalhes das animações, produzidas com vários desenhos dos personagens (DONDIS, 2000).

Em relação às cores, Walt discutiu com a Technicolor as cores básicas dos quadrinhos reproduzidos pelos jornais norteamericanos. Eram cores fortes e contrastantes, mas ele queria as cores da natureza. Seu personagem Grilo Falante, por exemplo, teve 27 cores diferentes, mas na produção para a televisão passou a ter nove (MOYA, 1996).

Walt queria cores em suas produções porque as via como reflexo da natureza, e o preto e branco não a representavam. Ele fez um contrato de exclusividade de dois anos com a Technicolor, que havia desenvolvido um sistema para filmes coloridos.

A primeira produção, de 1932, foi sobre a história de amor entre duas árvores, chamada Flores e árvores. O processo enriqueceu as produções da Disney e solidificou o sistema da Technicolor. Além disso, o filme ganhou um Oscar de melhor desenho animado em 1937 e, 30 anos depois, um prêmio especial da Academia (NADER, 2012).

Era notável a preocupação de Walt com a forma e as cores 
de seus trabalhos. Pesquisas feitas pela Gestalt indicam que pessoas emotivas são mais sensíveis aos estímulos das cores, enquanto as racionais respondem melhor à forma (ARNHEIM, 2013). Talvez essa tenha sido a estratégia para tornar a empresa e seus produtos populares, cumprindo o objetivo de alcançar o maior número possível de pessoas de diferentes idades.

Os efeitos especiais também eram importantes para Walt, cuja contribuição nesse campo foi a utilização de multiplanos. Salvador Dalí colaborou com os estúdios Disney em relação a essa técnica, produzindo trabalhos pintados em vidros com vários planos, o que realça a impressão de profundidade. Desse modo, os desenhos passaram a ser pintados em uma peça de vidro e colocados sequencialmente; as câmeras captavam as imagens com foco variável, ressaltando a figura sobre o fundo. Com a técnica, a Disney eliminou o achatamento das animações (MOYA, 1996).

As produções da Disney primaram pela sonorização e pela trilha sonora, porque o estímulo auditivo potencializa a compreensão da história. $\mathrm{O}$ aprimoramento da sonoplastia foi um processo contínuo, baseado no estudo de como a trilha sonora e o ritmo da película podem estimular o sentimento e o humor dos espectadores.

Percebe-se que sempre é colocada uma canção adocicada nos filmes, para torná-los sentimentais. Foi assim que Pinóquio ganhou um Oscar pela trilha sonora e a música When You Wish Upon a Star tornou-se um hino da Disney (MOYA, 1996).

Portanto, além de empregar em suas produções os princípios da Gestalt, como figura e fundo com contraste de cores, harmonia e aproximação (FILHO 2004), Walt Disney usou a sonoplastia para acentuar a percepção do público em relação à obra e para registrar em suas mentes a lembrança dos filmes.

Porém, os protagonistas das produções são os personagens. Walt dizia que os desenhistas deviam conhecê-los bem antes de começarem a desenhá-los. Era preciso ter consciência da personalidade e da identidade de cada um deles para que os desenhos 
ficassem expressivos, traduzindo os sentimentos de cada cena.

Como as expressões baseavam-se nos olhos, os estúdios tinham um vasto catálogo de olhos humanos e de diversos animais. Primeiro eram feitos esboços das expressões faciais e depois os corpos eram desenhados, com movimentos que reforçavam o significado da emoção do personagem na cena.

Para as dublagens, eram convidados atores famosos, como Peter Ustinov, que dublou o Rei João, e Terry Thomas, que deu voz a Sir Chio na animação Robin Hood, de 1973, a primeira após a morte de Walt Disney.

A personalidade marcante estendia-se aos vilões, que conquistavam o público por não serem totalmente maus. Cada personagem deveria ter vida própria e transmitir emoções, comunicando-se com todas as pessoas do mundo, de crenças, costumes e línguas diferentes. Um exemplo dessa estratégia é Bambi, cujo sucesso na URSS desestabilizou animadores russos que produziam desenhos intelectualizados e buscavam superar o padrão da Disney (MOYA, 1996).

O seriado Peter Punk apresenta as características marcantes das produções Disney, como as cores marcantes; a família constituída com membros de personalidade diferentes, porém unidos; os círculos de amizades; e os vilões que são na verdade adversários, que disputam com Peter a atenção do público.

\section{Apropriações do estilo punk pelo seriado Peter Punk}

O design gráfico do seriado Peter Punk apresenta as mesmas características do design gráfico adotado pelos punks, como a técnica do contraste nas colagens e as montagens fotográficas do dadaísmo, combinadas com a linguagem colorida da pop art, que predomina na linguagem do seriado e o aproxima do estilo new wave. 
O contraste de cores é coerente com as animações Disney, que em alguns casos utiliza a técnica da harmonia, na qual os elementos são percebidos e sustentam a figura principal. As cores primárias e cítricas, como amarelo, azul e verde, muito utilizadas pela pop art e pela new wave, são combinadas com o preto e o vermelho, que foram empregados pelos designers do movimento punk e representam o sangue operário (vermelho) e o poder do capitalismo (preto), conforme definiram os dadaístas no início do século XX, em suas composições que defendiam os interesses da classe operária (HOLLIS, 2010). Essa predominância de cores vivas infantiliza o estilo gráfico punk.

Essas características do design gráfico do punk são percebidas nas fotos dos personagens, em que são aplicados recortes irregulares como os adotados pelos punks e dadaístas. Os textos lembram tipografias feitas manualmente, uma característica do trabalho de Jamie Reid e Winston Smith, enquanto os títulos parecem compostos por recortes de revistas, similares aos dos álbuns dos Sex Pistols. Além disso, alguns banners digitais do seriado lembram a linguagem dos fanzines, com fotos em preto e branco como as do álbum Rocket to Russia, dos Ramones.

A composição da Disney é contrastante devido às cores vivas e aos grafismos, como os pontos da retícula de impressão visíveis, uma influência da pop art. Obtém-se, assim, uma linguagem gráfica de alta qualidade, produzida com recursos digitais e sem a espontaneidade do punk, do dadaísmo e da pop art. 
Figura 1: Fanzine Aviso Final, de Figura 2: RAMONES. Rocket to setembro de 1990.

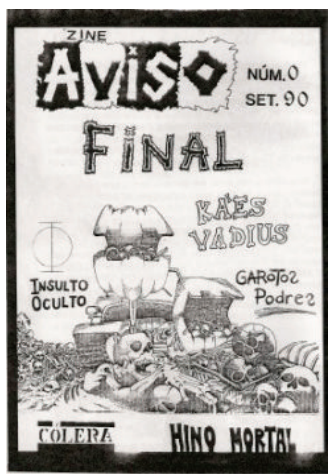
Russia, 1977. Capa de Arturo Vega.

Fonte: Disponível em: $<$ http://2. bp.blogspot.com/HM1ftAA7ie0/ TixOuZh6jPI/AAAAAAAAA8k/ dBxxcyz34QA/s320/

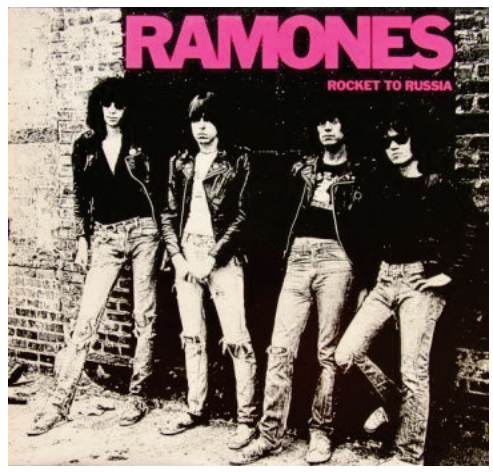
aviso\%2Bfinall.jpg > . Acesso em:

Fonte: Disponível em: $<$ https:// store.ramones.com/collections/ vinyl/products/ramones-rocket-torussia $>$. Acesso em: 17 out. 2016

17 out. 2016

Figura 3: Banner digital dos Rock Bones.

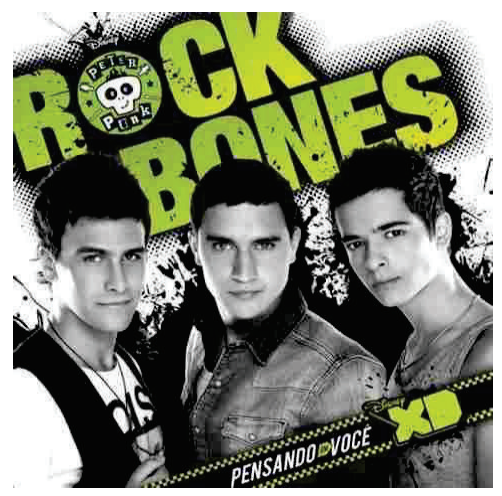

Fonte: Disponível em: $<$ http://peterpunkbr.blogspot.com.br/p/pm.html>. Acesso em: 5 mar. 2015. 


\section{Leitura do banner de Peter Punk}

\section{no site do canal Disney XD}

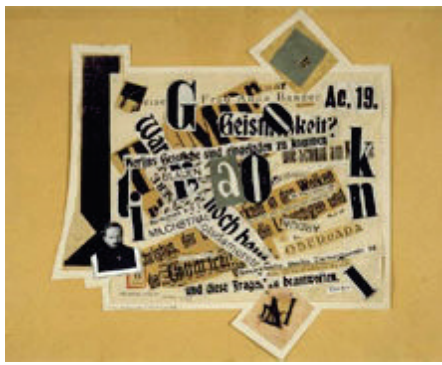

Figura 4: BAADER, Johannes.

Homenagem a Gutenberg.

Fonte: Disponível em: <http://ehoffmann. blogspot.com.br/2012/07/johannes-baader.

html>. Acesso em: 6 fev. 2015.

Figura 5: HARTFIELD, John. Fotomontagem da década de 1930.

Fonte: Disponível em: <http://lavrapalavra. blogspot.com.br/2012/12/john-heartfield-umfotografo-frente-de.html>. Acesso em: $6 \mathrm{fev}$. 2015.
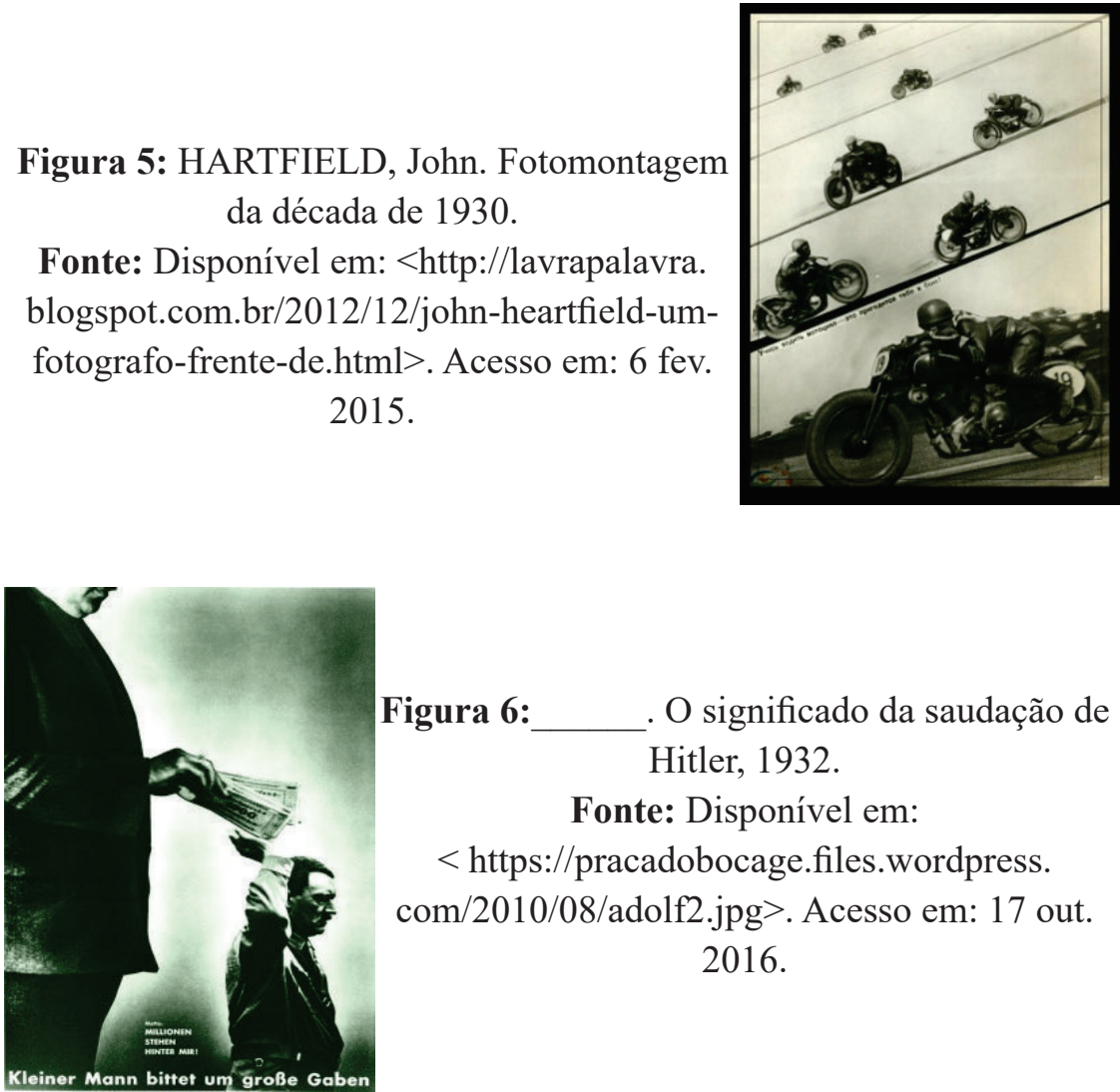

Figura 6: - O significado da saudação de Hitler, 1932.

Fonte: Disponível em:

$<$ https://pracadobocage.files.wordpress. com/2010/08/adolf2.jpg $>$. Acesso em: 17 out. 2016. 
Figura 7: LICHTENSTEIN, Roy. Oh Alright, 1964.

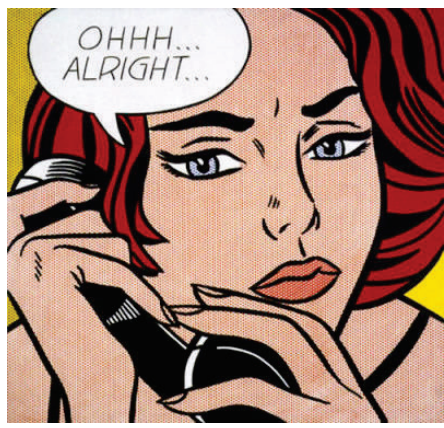

Fonte: Disponível em:

$<$ http://www.roylichtenstein.com/ images/paintings/ohhh-alright. jpg>. Acesso em: 17 out. 2016.
Figura 8: WARHOL, Andy. Marilyn Monroe, 1962.

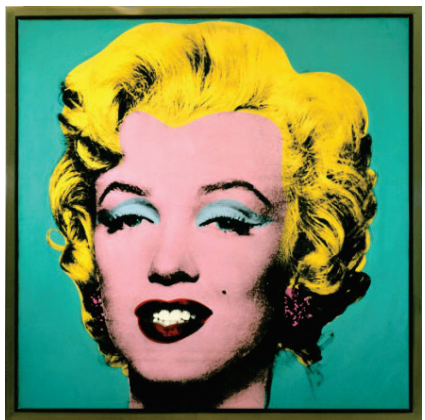

Fonte: Disponível em: $<$ http://virgula.uol.com.br/ album/diversao/conheca-asprincipais-obras-de-andyarhol/\#img=1\&galleryId=conhecaas-principais-obras-de-andywarhol>. Acesso em: 6 fev. 2015.

Figura 10: REID, Jamie. Debbie Harry-Punk. dos Buzzcocks no México, 2012
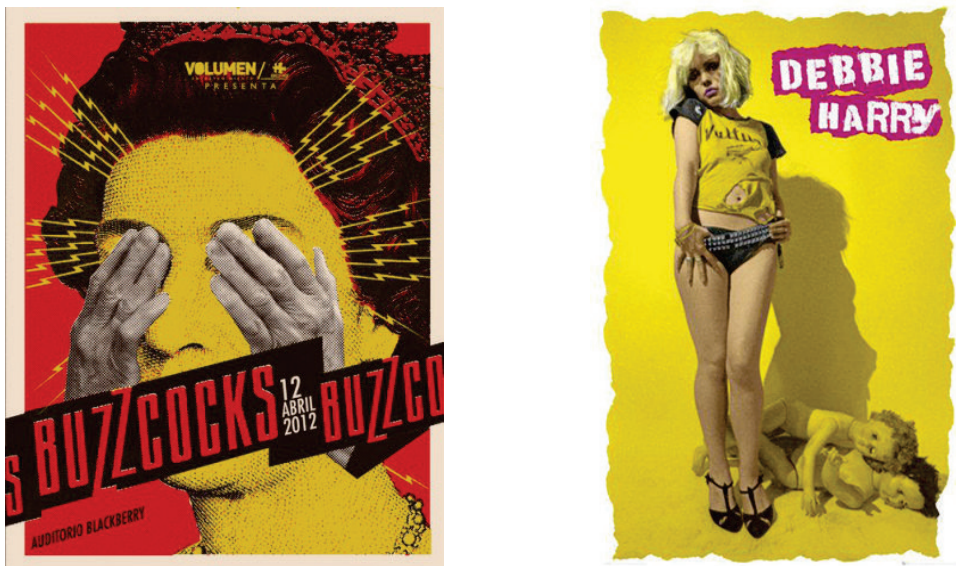
Fonte: Disponível em:

$<$ https://mir-s3-cdn-cf. behance.net/project
Fonte: Disponível em: $<$ http:// www.panicposters.com/blondiedebbie-harry-punk-poster.html>. modules/28785102.56053fdf574a7. Acesso em: 6 fev. 2015. jpg>. Acesso em: 17 out. 2016.

Figura 11: Banner de Peter Punk.

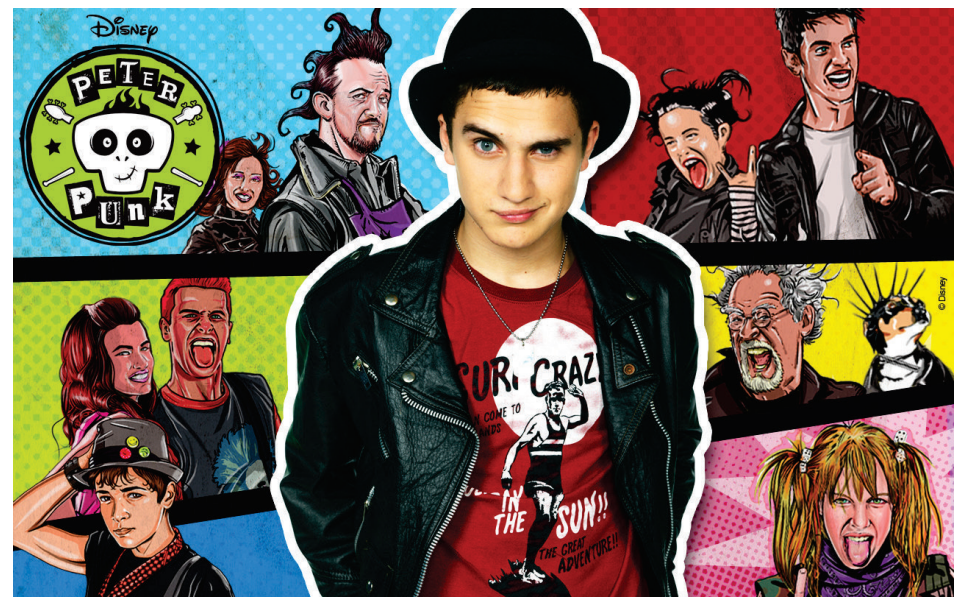

Fonte: Disponível em: $<$ https://ouvirmusica.com.br/peter-punk/>. Acesso em: 6 fev. 2015.

A figura 4 é a obra Homenagem a Gutenberg, de Johannes Theodor Baader, artista plástico e arquiteto alemão que produziu fotomontagens e colagens, foi um dos fundadores do Clube Dadá, e produziu em conjunto com Raoul Hausmann.

Essa obra reúne recortes de letras de diversos tamanhos e tipos de material, representando a variedade dos meios impressos, que só existem devido à invenção da imprensa por Gutenberg. A predominância da irregularidade influenciou designers como Winston Smith e Jamie Reid.

As figuras 5 e 6 são de John Heartfield. A primeira é uma fotomontagem com repetições. Os cortes diagonais remetem à 
velocidade e valorizam os novos conhecimentos proporcionados pela Revolução Industrial. A escala utilizada, com a figura em tamanhos diferentes, causa a impressão de profundidade e movimento, aguçando a interpretação.

Helmut Herzfeld adotou o nome artístico John Heartfield como uma forma de protesto contra o governo nacionalista alemão, que se opunha à política inglesa devido às sanções sofridas pela Alemanha com o final da Primeira Guerra Mundial. Seu trabalho de fotomontagem com imagens de Hitler e da suástica (figura 6) influenciou Jamie Reid, que utilizou o símbolo em trabalhos para os Sex Pistols e os Dead Kennedys, associando-o ao autoritarismo do regime capitalista.

A figura 7 é uma obra de Roy Lichtenstein, em que os traços pretos da linguagem dos quadrinhos delimitam o desenho, preenchido com cores sólidas. $\mathrm{O}$ estilo desmistifica tecnicamente o sistema de impressão ao revelar os pontos da retícula, que possibilitam a reprodução em grande escala.

A figura 8, Marilyn Monroe, de Andy Warhol, faz parte de uma série que transformou imagens comuns de personagens do cotidiano em arte. $\mathrm{O}$ trabalho de Andy Warhol em serigrafia com cores complementares mostra grande contraste e dinamismo.

A influência da pop art e do dadaísmo no estilo punk pode ser percebida em pôsteres como o dos Buzzcocks e o da banda Blondie. No pôster dos Buzzcocks, o dadaísmo está presente na foto da rainha Elizabeth com mãos sobre seus olhos. A irregularidade com que os textos foram dispostos, a forma como as cores foram aplicadas e os traços acrescentados à imagem lembram a pop art.

No cartaz do Blondie, a pop art predomina devido às cores quentes, que simbolizam a representatividade de Debbie Harry no cenário musical. Por sua beleza e elegância, ela foi apontada como a musa da new wave e do punk rock.

A figura 11, um exemplo extraído de um site brasileiro, apresenta características do dadaísmo, da pop art e do punk. A composição tem a tensão da linguagem gráfica desenvolvida pela 
fragmentação e pela assimetria. Percebe-se a influência do dadaísmo na montagem fotográfica e nas colagens, enquanto o punk é notado em elementos como o recorte impreciso da figura de Peter, a divisão irregular das imagens dos personagens e o logotipo. As influências da pop art são os traços no estilo cartum e o fundo com texturas, cores vibrantes e as retículas de impressão aparentes, o que remete à obra de Roy Lichtenstein.

A predominância da pop art torna a linguagem mais infantil. As cores da peça proporcionam tensão e dinamismo à linguagem. Do lado esquerdo, são combinadas cores frias, e do lado direito estão as quentes. A jaqueta preta de Peter neutraliza as cores vibrantes do fundo, e sua camiseta vermelha e o contorno branco de sua figura direcionam o olhar para o centro da peça, destacando o personagem principal da série.

\section{Considerações finais}

$\mathrm{Na}$ série Peter Punk, o design gráfico do punk sofreu transformações, mas ainda apresenta o arrojo do estilo. A sujeira habitual do punk, resultado dos recortes de imagens e de textos que compõem a colagem, é substituída por texturas rústicas e pontos semelhantes às retículas de impressão. Os títulos com variações tipológicas são simulados com a utilização de fontes digitais diferentes. As fotos, que no design gráfico do punk são apropriações, na série são recortes calculados de maneira irregular, para simular espontaneidade.

Em relação às cores, o design da série se aproxima da pop art de Andy Warhol, as texturas dos fundos assemelham-se às da obra de Roy Lichtenstein. Já as formas do design gráfico da série são fiéis ao punk e ao dadaísmo. Portanto, a proposta da Disney para o seriado consiste em um sutil desequilíbrio, uma boa combinação de cores e de contrastes de linguagens gráficas, o que resulta em uma ótima relação figura-fundo. 
As principais conclusões deste artigo são que o punk representa uma cultura periférica que influencia a dominante atualmente. A técnica do contraste utilizada pelos dadaístas e pela pop art foi adotada pelos punks por ser um meio visual de representar o desejo de mudança. $\mathrm{O}$ design gráfico da série representa o estilo punk com recursos produzidos por programas gráficos e por isto não é espontâneo e as cores da pop art estão presentes no estilo da série para tornar a linguagem infantil.

As principais inovações constatadas nas leituras das imagens podem ser classificadas como substanciais, devido à renovação e à recriação; qualitativas, por causa das alterações; espaciais, devido ao deslocamento do estilo punk do contexto da contracultura para o de um produto midiático de massa; e temporais, por causa dos recursos gráficos que incrementaram a linguagem punk. As inovações tornaram o estilo gráfico do seriado coerente com o público infantil, e reproduziram a espontaneidade do punk artificialmente com recursos tecnológicos.

\section{Referências}

ARNHEIM, Rudolf. Arte e percepção visual: uma psicologia da visão criadora. São Paulo: Cenage, 2013.

BENJAMIN, Walter. A obra de arte na era da reprodutibilidade técnica. In: LIMA, Luiz Costa (Org.). Teoria da cultura de massa. Rio de Janeiro: Paz e Terra, 1990.

BIVAR, Antonio. O que é punk? São Paulo: Brasiliense, 2001.

DONDIS, Donis A. Sintaxe da Linguagem Visual. São Paulo: Martins Fontes, 2000.

ELGER, Dietmar. Dadaísmo. Colônia: Taschen do Brasil, 2010. 
FILHO, João Gomes. Gestalt do objeto: sistema de leitura visual da forma. São Paulo: Escrituras, 2004.

HOLLIS, Richard. História concisa do design. São Paulo: Martins Fontes, 2010.

HONNEF, Klaus. Pop Art. Lisboa: Paisagem, 2004.

MEEGS, Philips Baxter. História do design gráfico. São Paulo: Cosac Naify, 2013.

MOYA, Alvaro de. O Mundo Disney. São Paulo: Geração Editorial, 1996.

NADER, Ginha. A Magia do império Disney. São Paulo: Senac, 2012.

OGG, Alex. Dead Kennedys: Fresh fruit for rotting vegetables (Os primeiros anos). São Bernado do Campo: Edições Ideal, 2014.

PRYSTHON, Ângela. Estudos culturais: uma (in)disciplina. Revista Comunicação e Espaço Público, ano VI, n. 1 e 2. Brasília: UNB, p. 134-141, 2004.

Disponível em: <http://www.fac.unb.br/site/images/stories/ Posgraduacao/Revista/Edicoes/2003_revista.pdf $>$. Acesso em: 20 mar. 2015.

TRUE, Everett, Hey Ho Let's Go: a história dos Ramones. São Paulo: Madras, 2013.

CUCHE, Denys. A noção de cultura nas ciências sociais. Bauru: Edusc, 1999. 